einstein

Official Publication of the Instituto Israelita

de Ensino e Pesquisa Albert Einstein

ISSN: 1679-4508 | e-ISSN: 2317-6385

\title{
Use of mouthwashes in the management of
} COVID-19 patients in intensive care units: recommendations and current evidence

\author{
Uso de colutórios no manejo de pacientes com COVID-19 em \\ unidades de terapia intensiva: recomendações \\ e evidências atuais \\ Marcos Roberto Tovani-Palone', Erfan Shamsoddin² \\ ${ }^{1}$ Faculdade de Medicina de Ribeirão Preto, Universidade de São Paulo, Ribeirão Preto, SP, Brazil.
${ }^{2}$ National Institute for Medical Research Development, Tehran, Iran.
}

DOI: 10.31744/einstein_journal/2021CE6419

Dear Editor,

According to recent studies, approximately $33 \%$ of patients hospitalized with coronavirus disease 2019 (COVID-19) should require intensive care, and up to $20 \%$ of those admitted to hospital may need invasive mechanical ventilation. $^{(1)}$ Considering the performance of multidisciplinary teams composed of physicians, nurses, dentists, physical therapists, and other health professionals at intensive care units (ICU) for treatment of COVID-19 patients, ${ }^{(2-4)}$ and evidence pointing to a decrease in viral load of severe acute respiratory syndrome coronavirus 2 (SARS-CoV-2) in saliva through the use of mouthwashes, ${ }^{(5,6)}$ some questions on this subject deserve to be discussed in more detail, focusing on safe approaches for the professional teams working in this context, as well as in relation to appropriate care for these patients.

First, based on the existing evidence, the use of mouthwashes in COVID-19 patients admitted to ICU is currently suggested before performing daily routine procedures with a potential risk of generating aerosols, and/or droplet emission during the care of intubated patients, and droplet release from those without intubation, which should undoubtedly contribute to reduce the risks of virus transmission to the team of health professionals at ICU ${ }^{(5)}$ (Table 1).

\begin{abstract}
How to cite this article:
Tovani-Palone MR, ShamsoddinE. Use of mouthwashes in the management of COVID-19 patients in intensive care units: recommendations and current evidence [letter]. einstein (São Paulo). 2021;19:eCE6419.
\end{abstract}

Received on:

Dec 30, 2020

\section{Accepted on:}

Jan 19, 2021

\section{Copyright 2021}

\section{(cc) BY}

This content is licensed

under a Creative Commons

Attribution 4.0 International License.
Table 1. Mouthwashes used in the treatment of COVID-19 patients admitted to intensive care units

\begin{tabular}{|c|c|c|}
\hline Recommended mouthwashes & Concentration & Main actions \\
\hline C31G (SAWY $\left.{ }^{\circledR}\right)$ & & Reduction of oral microorganisms in patients with COVID-19 \\
\hline Cetylpyridinium chloride & $0.05 \%$ & Possible antiviral effect on SARS-CoV-2 \\
\hline Povidone iodine & $0.2 \%, 0.4 \%$, or $0.5 \%$ & $\begin{array}{l}\text { Reduction of the SARS-CoV-2 viral load, contributing to the } \\
\text { control of oral hygiene and respiratory tract }\end{array}$ \\
\hline Hydrogen peroxide & $1.5 \%$ or $3 \%$ & Reduction of salivary viral load of SARS-CoV-2 \\
\hline Chlorhexidine & $0.12 \%$ & $\begin{array}{l}\text { Suppression of SARS-CoV-2 for } 2 \text { hours after use, improvement } \\
\text { of symptoms in COVID-19 patients presenting changes in oral } \\
\text { flora, and reduction of ventilator-associated pneumonia }\end{array}$ \\
\hline
\end{tabular}


Another important point concerning the use of mouthwashes in this group of patients is the contribution to improve of systemic problems associated with oral microbial flora, as well as to prevent the occurrence of nosocomial pneumonia associated with mechanical ventilation, leading to a probable reduction in the length of hospital stay ${ }^{(5)}$ (Figure 1). Also, the possibility of reducing the risk of cross-infection among hospitalized patients during the pandemic is expected as a secondary benefit. ${ }^{(6)}$

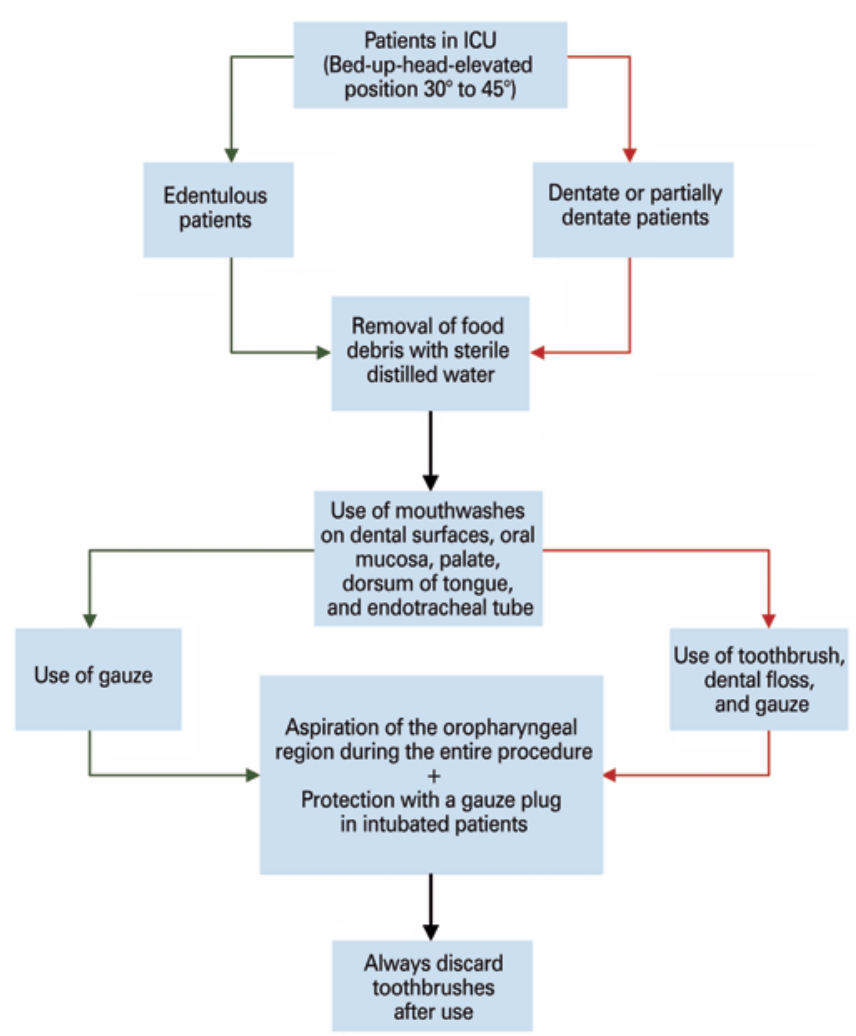

Source: adapted from Agência Nacional de Vigilância Sanitária (ANVISA). Gerência de Vigilância e Monitoramento em Serviços de Saúde. Gerência Geral de Tecnologia em Serviços de Saúde. Medidas de prevenção de infecção relacionada à assistência à saúde. v. 4. Brasília (DF): Ministério da Saúde; 2017. p. 92 [Série Segurança do Paciente e Qualidade em Serviços de Saúde] [cited 2020 Dec 26]. Disponivel em: https://www20.anvisa.gov.br/segurancadopaciente/index.php/ publicacoes/item/caderno-5; ${ }^{[7]}$ Conselho Federal de Odontologia (CFO). Recomendaçōes AMIB/CFO para atendimento odontológico COVID-19: Comitê de Odontologia AMIB/CFO de enfrentamento ao COVID-19. Brasilia (DF): AMIB/CFO; 2020 [cited 2020 Dec 26]. Disponivel em: http://www.crosp.org.br/uploads/arquivo/d45f45bec26af5e60711423292623321.pdf.81 ICU: intensive care units.

Figure 1. Recommendations for oral hygiene technique in COVID-19 patients admitted to intensive care units. Red arrows: applicable to dentate or partially dentate patients; green arrows: applicable to edentulous patients; black arrows: applicable to both groups

It is worth mentioning that for effective oral hygiene in COVID-19 patients admitted to ICU, some criteria must be carefully met. It is of utmost importance that each health care organization fits within its reality, regarding the combination of mouthwashes chosen. In figure 1 , we describe a proposal of steps to carry out this procedure.
Additionally, within this proposal, positioning patients with raised head mainly aims to avoid cases of pneumonia - due to healthcare-associated infections, while improving respiratory parameters. ${ }^{(7)}$ Furthermore, after initial aspiration of secretions above the cuff in intubated patients, the use of a gauze plug is recommended to complement the lung protection, which should be performed before the use of mouthwashes. ${ }^{(8)}$

However, even with fundamental advances in protocols for the management of ICU COVID-19 patients, the professional teams involved should always prioritize procedures with a lower risk of generating aerosols or droplet emission, which would provide greater security in the hospital environment. Moreover, the performance of intensive care dentists becomes essential to the comprehensive care of these patients.

\section{AUTHORS' INFORMATION}

Tovani-Palone MR: http://orcid.org/0000-0003-1149-2437

Shamsoddin E: http://orcid.org/0000-0003-4789-3697

\section{REFERENCES}

1. Bastos GA, Azambuja AZ, Polanczyk CA, Gräf DD, Zorzo IW, Maccari JG, et al. Clinical characteristics and predictors of mechanical ventilation in patients with COVID-19 hospitalized in Southern Brazil. Rev Bras Ter Intensiva. 2020; 32(4):487-92.

2. Corrêa TD, Matos GF, Bravim BA, Cordioli RL, Garrido AP, Assuncao MS, et al. Intensive support recommendations for critically-ill patients with suspected or confirmed COVID-19 infection. einstein (São Paulo). 2020;18:eAE5793.

3. Pedersini P, Villafañe JH, Corbellini C, Tovani-Palone MR. COVID-19 pandemic: a physiotherapy update. Electron J Gen Med. 2021;18(1):em264.

4. Passarelli PC, Passarelli G, Charitos IA, Rella E, Santacroce L, D'Addona A COVID-19 and oral diseases: how can we manage hospitalized and quarantined patients while reducing risks? Electron J Gen Med. 2020;17(6):em238.

5. Moosavi MS, Aminishakib P, Ansari M. Antiviral mouthwashes: possible benefit for COVID-19 with evidence-based approach. J Oral Microbiol. 2020;12(1):1794363. Review.

6. Vergara-Buenaventura A, Castro-Ruiz C. Use of mouthwashes against COVID-19 in dentistry. Br J Oral Maxillofac Surg. 2020;58(8):924-7. Review.

7. Agência Nacional de Vigilância Sanitária (ANVISA). Gerência de Vigilância e Monitoramento em Serviços de Saúde. Gerência Geral de Tecnologia em Serviços de Saúde. Medidas de prevenção de infecção relacionada à assistência à saúde. v. 4. Brasília (DF): Ministério da Saúde; 2017. p. 92 [Série Segurança do Paciente e Qualidade em Serviços de Saúde] [citado 2020 Dez 26]. Disponível em: https://www20.anvisa.gov.br/segurancadopaciente/ index.php/publicacoes/item/caderno-5

8. Conselho Federal de Odontologia (CFO). Recomendações AMIB/CFO para atendimento odontológico COVID-19: Comitê de Odontologia AMIB/CFO de enfrentamento ao COVID-19. Brasília (DF): AMIB/CFO; 2020 [citado 2020 Dez 26]. Disponível em: http://www.crosp.org.br/uploads/arquivo/ d45f45bec26af5e60711423292623321.pdf 